Sylwia Czerwińska, Beata Jaskuła, Monika Jędra-Legezińska, Marcelina Kietla, Agata Sech, Barbara Stolarska

\title{
Międzynarodowe Centrum Usług Zakupowych Philips jako przykład siły offshoringu w dobie globalizacji
}

\section{Wstęp}

Nasilenie się globalnej konkurencji z jednej strony, z drugiej zaś chęć sprostania regionalnym wymaganiom konsumentów zmusiły korporacje międzynarodowe do reorganizacji swoich struktur przy użyciu nowych modeli zarządzania. Wśród wielu dostępnych strategii, jedną z częściej wybieranych jest zarządzanie z wykorzystaniem offshoringu, polegającego na przetransferowaniu części działań biznesowych i ulokowaniu ich poza granicami kraju firmy macierzystej.

Główną korzyścią dla przedsiębiorstwa z tytułu wdrożenia offshoringu jest rozwój w sferze usług świadczonych dla podległych jednostek oraz wzrost rozpoznawalności marki i zbliżenie się do regionalnych rynków zbytu dzięki przeniesieniu części działalności do innego kraju.

Jedną z najszybciej rozwijających się w naszym kraju lokalizacji dla tego typu inwestycji jest Łódź. W przeciągu niespełna kilkunastu lat swoje siedziby utworzyło tutaj kilkanaście firm zagranicznych. Wśród nich znalazł się holenderski producent sprzętu elektronicznego - Royal Philips Electronics, który otworzył w Łodzi międzynarodowe centrum usług zakupowych i finansowych (Shared Service Center). 


\section{Idea offshoringu}

\subsection{Offshoring - definicje, typy, perspektywy rozwoju}

Zgodnie z definicją dr D. Ciesielskiej, offshoring jest to zmiana $\mathrm{w}$ funkcjonowaniu międzynarodowego biznesu, występująca pod wpływem rozwoju technologii telekomunikacyjno-informacyjnych, nasilającej się globalnej konkurencji oraz liberalizacji przepisów dotyczących międzynarodowego handlu usługami. Polega ona na wydzieleniu części usług biznesowych, IT i badawczo-rozwojowych, a następnie przekazaniu ich do wykonania przedsiębiorstwom w krajach o niższych kosztach pracy lub o większych zasobach kapitału intelektualnego.

W literaturze przedmiotu można spotkać się z zamiennym używaniem terminów outsourcing i offshoring, lecz pojęcia te nie są tożsame. Pojęcie outsourcing (Outsider Resorce Using) oznacza wykorzystanie zasobów zewnętrznych i wiąże się z podwykonawstwem oraz z nawiązaniem długotrwałej współpracy z kontrahentem i przebudową otoczenia zasadniczej działalności. Innymi słowy, jest to przesunięcie zamówień, produkcji lub usług do innej firmy.

Offshoring zaś jest przeniesieniem wybranych procesów biznesowych przedsiębiorstwa poza granicę kraju. Dotyczy to procesów takich, jak produkcja, usługi lub zamówienia. Przeniesienie może nastąpić w ramach tego samego przedsiębiorstwa lub innego, zewnętrznego. Według UNCTAD offshoring to ,proces polegający na wytwarzaniu usług na terytorium innego państwa. Może być przeprowadzany przez firmę na zasadzie działań wewnętrznych (captive offshoring) lub poprzez outsorcing do zagranicznego kontrahenta (offshore outsourcing)". W tym drugim przypadku mamy więc do czynienia z procesem hybrydowym, łączącym cechy outsourcingu i offshoringu (rys. 1). Na potrzeby niniejszej publikacji przyjmujemy rozumienie terminu offshoring odnoszące się do definicji captive offshoring. 


\section{TRANSFER CZĘŚCI BIZNESU}

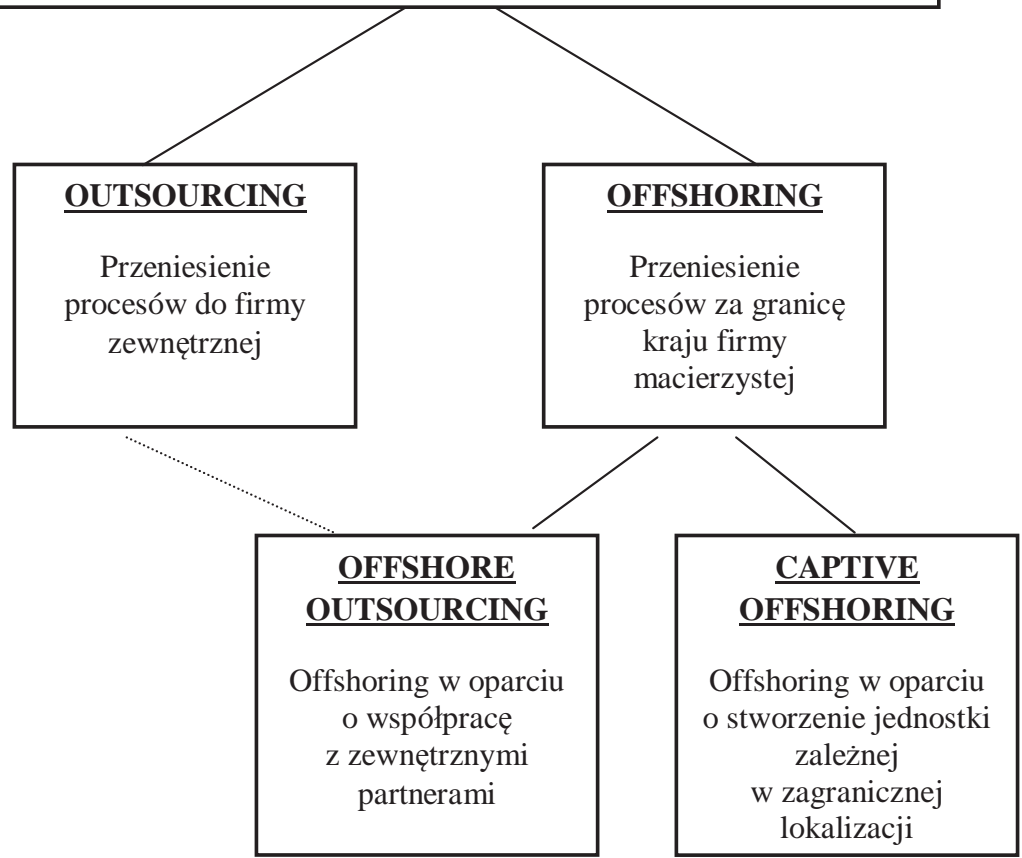

Rysunek 1. Uproszczony model transferu części biznesu

Źródło: opracowanie własne

Jeżeli chodzi o sferę usług, offshoring określany jest jako zjawisko polegające na przenoszeniu przez przedsiębiorstwo za granicę czynności, które uprzednio były wykonywane w danym kraju. Obecnie offshoring dotyczy nowych typów usług, w szczególności tych, których przekazywanie na dalekie odległości stało się możliwe dzięki rozwojowi technologii telekomunikacyjno-informatycznych ${ }^{1}$.

1 A. Szymaniak, Globalizacja Ustug, Outsourcing, Offshoring i Shared Service Centers, Wydawnictwo Akademickie i Profesjonalne, Warszawa 2008, s. 189-191. 
Wbrew obiegowej opinii offshoring nie jest jedynie odpowiedzią na potrzebę zmniejszenia kosztów pracy poprzez przenoszenie jej do krajów nisko rozwiniętych lub rozwijających się. W wielu przypadkach oznacza to przenoszenie usług do krajów, które posiadają wysoko rozwiniętą infrastrukturę naukowo-badawczą oraz charakteryzujących się stosunkowo wysokimi kosztami zatrudnienia i prowadzenia działalności organizacyjnej. Jest to w znacznym stopniu uwarunkowane dążeniem organizacji do tworzenia wartości poprzez zapewnienie sobie dostępu do międzynarodowych zasobów kapitału intelektualnego, innowacji technicznych oraz możliwości ekspansji na globalne rynki zbytu².

Intensywny rozwój offshoringu wynika ze zwiększającego się zapotrzebowania na nowe typy usług, które są generowane przez nowoczesne przedsiębiorstwa. W szczególności są to usługi będące produktami pośrednimi, gdzie decydujące znaczenie mają zasoby intelektualne, wiedza i informacja. Powodzenie offshoringu zależy od wielu czynników, takich jak: sytuacja ekonomiczna, nasilenie globalnej konkurencji, liberalizacja w handlu usługami czy rozwój technologiczny. Przedsiębiorstwo poprzez wdrożenie offshoringu korzysta z globalnych zasobów kapitału ludzkiego oraz uzyskuje korzyści finansowe, które wynikają z niższych kosztów operacyjnych ${ }^{3}$. Wiąże się to z pozostawieniem usług kluczowych dla przedsiębiorstwa w kraju macierzystym, a przeniesieniu jedynie tych operacji, które pełnią funkcję pomocniczą dla biznesu.

\subsection{Offshoring procesów biznesowych}

Offshoring procesów biznesowych stał się popularny wśród korporacji międzynarodowych w latach 90 . XX w. Delokalizacja zasobów i działalności przedsiębiorstw wymusiła zmiany w ich funkcjonowaniu poprzez stworzenie centrów koordynacji funkcjonowania organizacji w skali globalnej. Centra te stały się swego rodzaju pośrednikiem mię-

2 www.egospodarka.pl [dostęp: 29.08.2012].

3 D. Ciesielska, Offshoring ustug wpływa na rozwój przedsiębiorstwa, Wydawnictwo Oficyna Wolters Kluwer business, Warszawa 2009, s. 32-34. 
dzy rozproszonymi geograficznie sieciami współpracujących ze sobą jednostek organizacyjnych a główną siedzibą firmy ${ }^{4}$.

Omawiana koncepcja w ostatnim okresie stała się często wdrażaną strategią biznesową przez firmy, które poszukują oszczędności i nowych zasobów kapitału ludzkiego, a zarazem dążą do zwiększenia efektywności pracy oraz podniesienia jakości wykonywanych usług. Najczęściej przenoszonymi procesami biznesowymi są: finanse i księgowość, usługi prawne, call centers, usługi inżynieryjne, analizy i badania rynku oraz przetwarzanie danych ${ }^{5}$. Są one świadczone w ramach nowo powołanych jednostek zwanych ogólnie Shared Service Centers.

Zgodnie z podziałem zaproponowanym przez dr D. Ciesielską, przykładem Shared Service Center (SSC), czyli procesu biznesowego, w którym centrum przejmuje funkcje biznesowe od korporacji macierzystej i tworzone jest w miejscach, gdzie niskie koszty pracy występują w połączeniu z wysoką wydajnością oraz jakością, jest Philips SSC Łódź.

\subsection{Offshoring w Polsce}

Offshoring stanowi dla przedsiębiorstwa źródło przewagi konkurencyjnej i przesądza o rozwoju firmy. Jest on uzależniony od dwóch zmiennych $-\mathrm{z}$ jednej strony od odpowiednio wykwalifikowanych pracowników, z drugiej zaś - od wykorzystania nowych technologii informatycznych. Wybór państwa, w którym zostanie stworzone centrum offshoringowe, zależy od takich parametrów, jak: stawki płac, ulgi dla przedsiębiorstw, skala podatków, zasoby kapitału ludzkiego oraz struktury gospodarki w danym państwie. Coraz częściej działalność offshoringowa nie sprowadza się jedynie do przekazywania funkcji operacyjno-wspierających, ale dotyczy także usług skomplikowanych, opartych na wiedzy i dostarczających coraz większą wartość dodaną przedsiębiorstwu.

${ }^{4}$ K. Kłosiński, A. Masłowski, Globalizacja sektora usług w Polsce, Polskie Wydawnictwo Ekonomiczne, Warszawa 2005, s. 15-16.

5 D. Ciesielska, Offshoring ustug..., s. 32-34. 
O tym, jak duże znaczenie mają obecnie tego typu usługi biznesowe, świadczy ogromna liczba nowo powstających centrów offshoringowych w Polsce. Tylko w latach 2009-2011 pracę w tych centrach znalazło 28 tys. nowych pracowników, a według prognoz - w 2012 r. sektor ten będzie zatrudniał ok. 100 tys. osób ${ }^{6}$. Polska posiada dobre warunki do tego typu inwestycji ze względu na swoje położenie geograficzne, dostęp do wykwalifikowanej kadry, podobieństwa kulturowe do krajów wysoko rozwiniętych oraz poziom płac adekwatny do efektywności zatrudnionych ${ }^{7}$. Dzięki powyższym czynnikom w 2011 r. nasz kraj dołączył do grupy państw dojrzałych do inwestycji offshoringowych ${ }^{8}$.

\section{4. Łódź jako miasto usług offshoringowych - potencjał miasta}

Centra zaplecza biznesowego (tzw. BPO - Business Process Outsourcing) to jedna z priorytetowych branż w Lodzi. Miasto jest atrakcyjne dla inwestorów przede wszystkim ze względu na dużą dostępność pracowników oraz niskie koszty prowadzenia działalności gospodarczej - niski poziom płac oraz konkurencyjne ceny powierzchni biurowych.

Łódź jest trzecim pod względem liczby ludności miastem w Polsce (w 2011 r. zameldowanych było ok. 737 tys. osób) i czwartym pod względem powierzchni $\left(293,25 \mathrm{~km}^{2}\right)$. Atutem miasta jest jego lokalizacja - centralne położenie względem większości stolic Europy Środkowej oraz największych miast Polski. Łódź jest usytuowana na skrzyżowaniu powstających autostrad A1 i A2, drogi ekspresowej S8 oraz zachodniej obwodnicy S14. Ponadto w mieście znajduje się port lotniczy, który obsługuje zarówno loty krajowe, jak i połączenia międzynarodowe.

Co więcej, Łódź jest dużym ośrodkiem akademickim, w którym funkcjonuje 6 uczelni państwowych oraz 18 prywatnych. Kształci się

\footnotetext{
6 M. Kaczmarczyk, Hit eksportowy, „Forbes” 2012, No 9.

7 D. Ciesielska, Offshoring ustug..., s. 78.

${ }^{8}$ M. Kaczmarczyk, Hit...
} 
tutaj ponad 120 tys. studentów, z których kilkadziesiąt tysięcy rocznie uzyskuje dyplom? .

Dla konkurencyjności miasta nie bez znaczenia są również aspekty finansowe. Przeciętne wynagrodzenie brutto $\mathrm{w}$ sektorze przedsiębiorstw w 2011 r. wyniosło 3197,77 zł i było najniższe w porównaniu z innymi dużymi miastami kraju. Najwyższe wynagrodzenie odnotowano w Warszawie. Zarobki w Łodzi w porównaniu do stolicy były niższe o $31,7 \%$, natomiast w stosunku do najbardziej zbliżonego pod względem poziomu płac Wrocławia i Krakowa - o około 11-13\%. Jeśli chodzi o wzrost wynagrodzeń, największy zanotowano w Krakowie i Poznaniu (odpowiednio 6,7\% i 4,9\%), umiarkowany - w Warszawie $(4,4 \%)$, a najniższy $-\mathrm{w}$ Łodzi $(2,8 \%)^{10}$.

Poniższa tabela przedstawia przeciętne miesięczne wynagrodzenie brutto w sektorze przedsiębiorstw w Łodzi w porównaniu z innymi dużymi miastami w Polsce. Zestawienie prezentuje wyniki z lat 2011 i 2003 (wtedy na terenie miasta zaczęło funkcjonować biuro Philips).

Tabela 1. Przeciętne miesięczne wynagrodzenie brutto w sektorze przedsiębiorstw w 2003 oraz 2011 r. (w zl)

\begin{tabular}{cccccc}
\hline Rok & Wroclaw & Warszawa & Poznań & Lódź & Kraków \\
\hline 2003 & 2223 & 3227 & 2518 & 2037 & 2223 \\
\hline 2011 & 3600 & 4682 & 4032 & 3198 & 3668 \\
\hline
\end{tabular}

Źródło: Sytuacja społeczno-gospodarcza Łodzi - lata 2011, 2003, Urząd Statystyczny w Lodzi.

Średnie wynagrodzenie w Łodzi, w porównaniu z innymi dużymi miastami kraju, nadal utrzymuje się na najniższym poziomie. Niskie koszty pracy stanowią silny argument przy wyborze lokalizacji nowych inwestycji.

Atutem miasta jest również duży potencjał w zakresie powierzchni biurowej, która na koniec 2012 r. wynosić będzie ponad 200 tys. m².

${ }^{9}$ www.uml.lodz.pl [dostęp: 03.09.2012].

10 Sytuacja spoteczno-ekonomiczna w Łodzi, BIP 2011. 
Łódź dysponuje nowoczesnymi biurowcami, a koszty najmu są konkurencyjne $\mathrm{w}$ porównaniu do stawek oferowanych $\mathrm{w}$ innych dużych miastach. Budynki zlokalizowane są w centrum, a w biurowcach klasy A ceny najmu wynoszą $11-13,5 € / \mathrm{m}^{11}$.

$\mathrm{Na}$ koniec grudnia 2011 r., według danych z lokalnego rynku pracy, podwyższeniu uległy podstawowe wskaźniki określające bezrobocie. Liczba osób bezrobotnych w Łodzi wzrosła z 33,7 tys. do 37 tys., przy jednoczesnym wzroście stopy bezrobocia, która na koniec grudnia 2011 r. wynosiła w Łodzi 10,8\% i była najwyższa w kraju, obok Białegostoku $(12,4 \%)^{12}$.

Zestawienie poziomu stóp bezrobocia, prezentujące Łódź na tle dużych miast w 2003 oraz 2011 r., przedstawia tabela 2.

Tabela 2. Stopy bezrobocia w Łodzi na tle dużych miast w 2003 oraz 2011 r. (w \%)

\begin{tabular}{cccccc}
\hline Rok & Wroclaw & Warszawa & Poznań & Lódź & Kraków \\
\hline 2003 & 12,9 & 6,1 & 7,1 & 19,1 & 8,4 \\
\hline 2011 & 5,0 & 3,8 & 3,7 & 10,8 & 4,9 \\
\hline
\end{tabular}

Źródło: Sytuacja społeczno-gospodarcza Łodzi - lata 2011, 2003, Urząd Statystyczny w Łodzi.

Od 2003 r. stopa bezrobocia w Łodzi obniżyła się o ponad 8 pkt procentowych, mimo to jest nadal najwyższa $\mathrm{w}$ porównaniu $\mathrm{z}$ innymi dużymi miastami Polski.

Zasoby kapitału ludzkiego, niskie stawki płac oraz dostępne nowoczesne powierzchnie biurowe to istotne elementy wpływające na atrakcyjność inwestycyjną miasta. Łódź, jako centrum BPO, specjalizuje się przede wszystkim w finansach, księgowości oraz IT, stanowi siedzibę dla 30 firm z tej branży, będących miejscem pracy dla kilkunastu tysięcy łodzian ${ }^{13}$.

\footnotetext{
11 www.bpo.lodz.pl [dostęp: 07.09.2012].

12 Sytuacja społeczno-ekonomiczna...

13 „Outsourcing \& More” 2012, No 4(5), s. 38.
} 


\section{Philips jako przykład wykorzystania offshoringu}

\subsection{Historia firmy}

Firma Royal Philips Electronics, potocznie nazywana Philips, należy do światowej czołówki firm działających w szeroko rozumianej branży sprzętu elektronicznego. Przez ponad 120 lat istnienia koncern wypracowywał sobie renomę i obecnie posiada kilkadziesiąt lokalizacji w różnych częściach świata.

Dzisiejsza pozycja Philipsa jest efektem wieloletniej działalności, której początek miał miejsce w Eindhoven pod koniec XIX w. W roku 1891 bracia Anton i Gerard Philips powołali do życia przedsiębiorstwo Philips\&Co., pierwotnie zajmujące się produkcją lamp żarowych. Jednak dzięki ciągłym inwestycjom w rozwój technologii portfolio szybko zostało poszerzone (rys. 2), a w ciągu niespełna dwudziestu lat firma stała się największym pracodawcą na rynku holenderskim oraz jednym z głównych producentów żarówek w Europie.

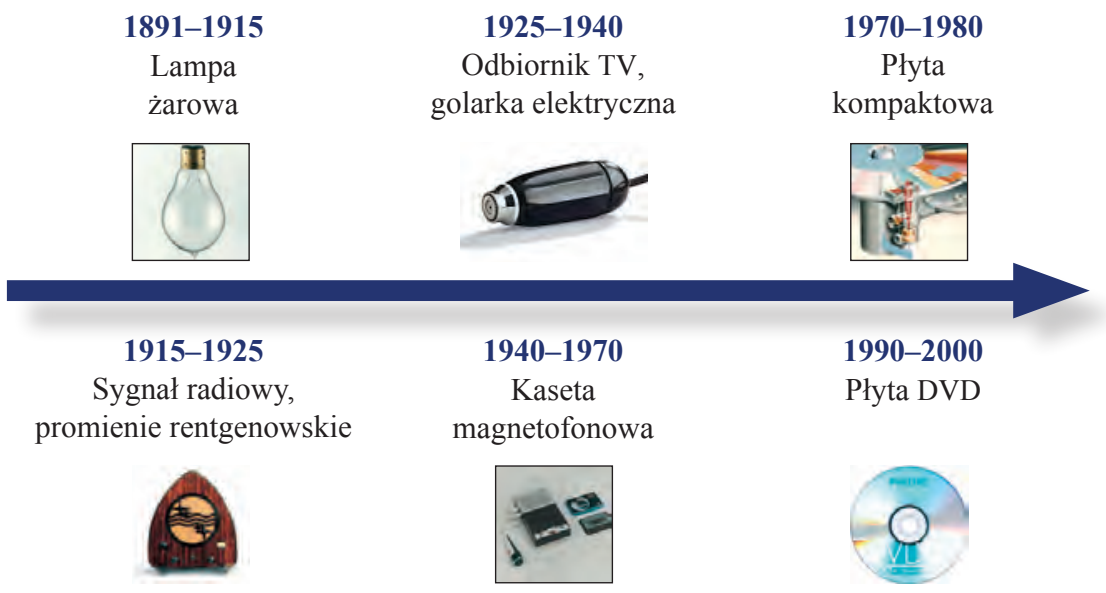

Rysunek 2. Najważniejsze etapy rozwoju i wynalazki marki Philips

Źródło: opracowanie własne na podstawie Our heritage; www.philips.com

[dostęp: 21.08.2012] 
Obecnie działalność Philipsa skupia się w trzech obszarach. Jednak przez długie lata głównym sektorem pozostawał sektor oświetleniowy (lighting). Mając kilkudziesięcioletnie doświadczenie na tym rynku, Philips stał się jednym z jego liderów. Oferta adresowana jest do rozległej grupy odbiorców, wśród których znajdują się zarówno konsumenci, jak i jednostki sektora biznesowego. Projektowane rozwiązania oświetleniowe znajdują zastosowanie między innymi w takich obiektach, jak: szkoły, sklepy/supermarkety, domy, biura i obiekty przemysłowe, przestrzeń miejska - drogi, parki, osiedla itp.

Drugim, mniej znanym polskim konsumentom, obszarem aktywności jest sektor ochrony zdrowia (healthcare). Produkty Philips wykorzystywane są we wszystkich fazach leczenia - od profilaktyki do momentu postawienia diagnozy, aż po proces leczenia.

Poza wymienionymi sektorami, koncern działa również w sferze produktów konsumenckich (consumer lifestyle). Oferta zawiera szeroką gamę produktów przydatnych w codziennym życiu. Do najistotniejszych dziedzin należą: zdrowie i samopoczucie, golenie i pielęgnacja urody oraz urządzenia RTV i AGD użytku codziennego.

Dzięki dotychczasowym osiągnięciom w nowy wiek Philips wkroczył w gronie światowych liderów branży elektronicznej, a jego marka uplasowała się na 41 pozycji najbardziej wartościowych marek świata $\mathrm{w}$ rankingu Interbrand $2011^{14}$. Obecnie firma zatrudnia ponad 120 tys. pracowników w ponad 60 krajach, wśród których znalazła się Polska.

\subsection{Rozwój Philips w Polsce}

Philips zadebiutował na polskim rynku w roku 1921, stając się jednym z udziałowców Fabryki Lampek Elektrycznych. W przeciągu roku uruchomiona została produkcja lamp Philips, której poziom dochodził do 30 tys. sztuk dziennie.

${ }^{14}$ www.interbrand.com [dostęp: 21.08.2012]. 

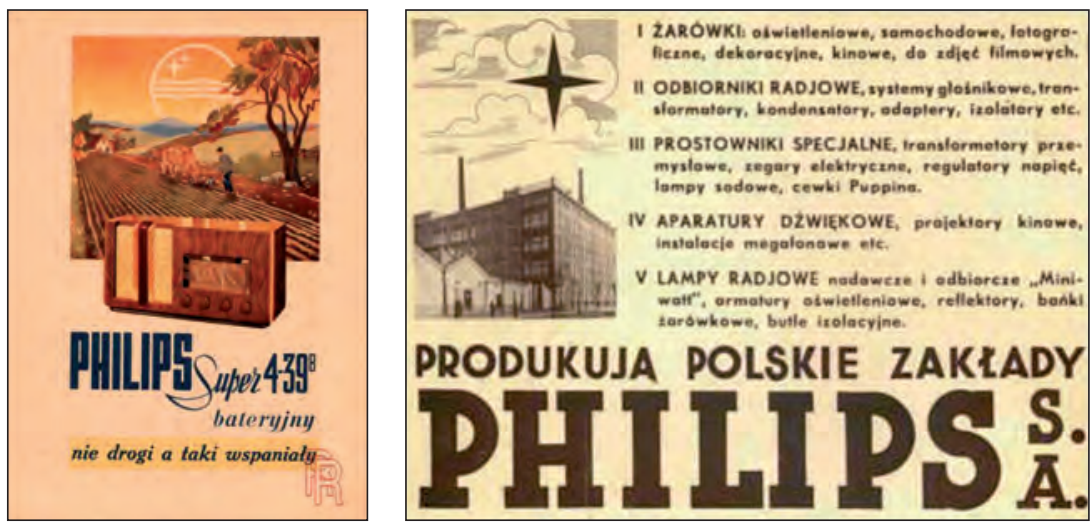

Fot. 1. Archiwalne reklamy produktów Philips

Źródło: www.radioretro.pl, www.lighting.pl [dostęp: 20.08.2012]

Dwa lata później w Warszawie powstała kolejna fabryka sprzętu oświetleniowego, w której zatrudnienie znalazło ponad 200 osób. Był to również początek rozwoju sieci sprzedaży w Polsce. W kolejnych latach producent rozszerzył swoje inwestycje o wytwórnie odbiorników radiowych oraz sprzedaż aparatów rentgenowskich, dzięki którym zatrudnienie znalazło ponad 2 tys. osób.

Mimo ogromnych nakładów lata wojny znacząco odbiły się na działalności Philips w kraju. Placówki firmy znalazły się pod zarządem niemieckim i zmuszone były do pracy na rzecz III Rzeszy. W tym czasie kierownictwo holenderskie popierało ruch oporu, który był wspierany przez pracowników fabryki.

W wyniku działań wojennych, jakie miały miejsce w stolicy, zakłady Philips zostały dotkliwie zniszczone. Mimo prób odbudowy i ich reaktywacji, skutkiem było tymczasowe wycofanie się koncernu z tego rynku, aż do końca lat 80. W roku 1991 holenderski gigant powrócił do Polski, stając się większościowym udziałowcem zakładów Polam-Piła, a w niedługim czasie otwarta została również placówka marketingowo-sprzedażowa w Warszawie. Od tego czasu Royal Philips Electronics umacnia swoją pozycję, stając się jednym z największych eksporterów i inwestorów zagranicznych na polskim rynku. 
Obecnie koncern zatrudnia w Polsce ponad 7 tys. pracowników w 4 zakładach produkcyjnych oraz organizacji marketingowo-sprzedażowej. Fabryki ulokowane są w Pile, Pabianicach, Kętrzynie, Bielsku-Białej. Pozostałe jednostki mają swoje siedziby w największych miastach centralnej części kraju - Warszawie i Łodzi.

\section{Offshoring w praktyce - Philips SSC Łódź}

\subsection{Geneza powstania}

Jedną z najmłodszych jednostek Philips w Polsce jest Shared Service Center w Łodzi. Organizacja powstała 1 sierpnia 2003 r. jako centrum finansowo-księgowe (European Accounting Services), a w 2004 r. poszerzyła swoją działalność o usługi zakupowe (European Service Center).

Zgodnie z rozwijającym się trendem outsourcingowym, a także ze względu na rosnącą konkurencję i coraz bardziej wymagającą sytuację rynkową, Philips, jako firma innowacyjna i chętnie wdrażająca pionierskie rozwiązania, zdecydował o wprowadzeniu nowego modelu biznesowego. Polega on na wyodrębnieniu działów księgowo-finansowych oraz zakupowych (nieprodukcyjnych - związanych z produktami lub usługami, które nie wchodzą w skład produktu końcowego firmy) z poszczególnych jednostek firmy i połączeniu ich $\mathrm{w}$ jedną organizację centralną z kilkoma lokalizacjami. Uznano, że nie będzie to outsourcing usług na zewnątrz, ale scentralizowanie ich wewnątrz firmy, na zasadzie captive offshoring.

W rezultacie w centrum Łodzi powstało Shared Service Center (SSC Łódź) zatrudniające ok. 800 osób i obsługujące europejskie podmioty firmy. Jest ono zatem przykładem wykorzystania nurtu, gdzie działania wewnętrzne polegające na stworzeniu oddziału lub spółki zależnej pod względem kapitałowym w innym państwie zapewniają przedsiębiorstwu kontrolę nad procesem wytwarzania dóbr i usług ${ }^{15}$.

${ }_{15}$ D. Ciesielska, Offshoring ushug..., s. 11. 
W następnej kolejności utworzono podobne jednostki w Tajlandii (jednostka później przeniesiona do Chin), Indiach i Brazylii, obsługujące klientów wewnętrznych z Ameryki i Azji.

Droga do wyłonienia się scentralizowanej organizacji zakupowej była dość długa. W latach 90. XX w., zastanawiając się jak najefektywniej zarządzać zakupami nieprodukcyjnymi, Philips powołał organizację zakupową nazwaną Philips General Purchasing (PGP). Ten globalny dział zakupów pracował nad strategiami i tworzył politykę zakupową dostosowaną do warunków rynków lokalnych. Aby móc realizować tę politykę, PGP potrzebował odpowiedniego procesu operacyjnego oraz wsparcia ze strony zespołu, który czuwałby nad jej przestrzeganiem. W tym celu stworzono w Holandii Transactional Shared Service Center (TSSC), przeniesione później do Polski. W ciągu trzech lat centrum, zatrudniające na początku 10 osób, rozwinęło się w organizację obsługującą jednostki Philips w całej Europie.

Równolegle powstawała organizacja finansowo-księgowa. Ta scentralizowana jednostka operacyjna utworzona została najpierw w Irlandii, a po krótkim czasie, w 2003 r. przeniesiono ją do Łodzi.
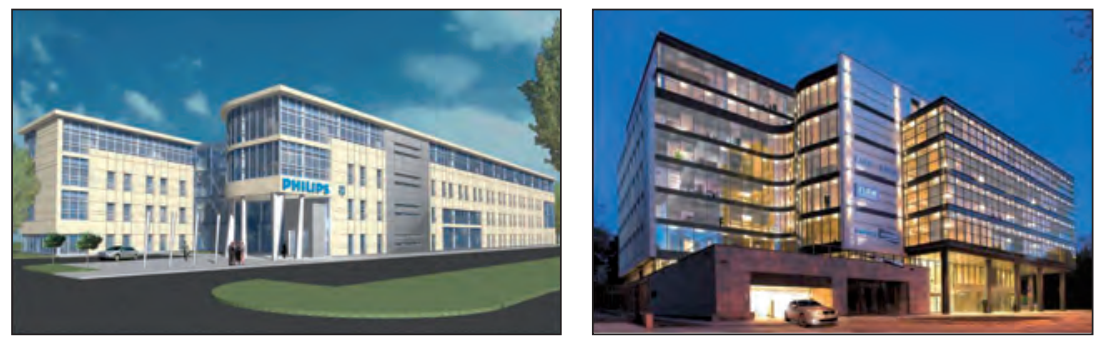

Fot. 2. Pierwotna i obecna siedziba Philips SSC Łódź

(od lewej: budynek przy ul. Piłsudskiego 22; budynek przy ul. Sterlinga 8a)

Źródło: zbiory własne, Hines Polska sp. z o.o., www.sterlinga-bc.pl [dostęp: 14.09.2012]

Z biegiem czasu łódzkie centrum zmieniało się i rozwijało, przejmując sukcesywnie kolejne jednostki firmy, tak aby osiągnąc stabilną formę Financial Shared Service Center (FSSC) i Transactional Shared 
Service Center (TSSC). W efekcie globalnego projektu outsourcingowego, w 2007 r. dobrze funkcjonująca organizacja została przekazana w zarządzanie firmie Infosys BPO. Zanim to jednak nastąiło, w TSSC miał miejsce podział zespołu na dwie grupy: jedną transakcyjną - zajmującą się przetwarzaniem i aprobowaniem zamówień nieprodukcyjnych (Non Product Related - NPR), drugą - usprawniającą proces oraz wspierającą go poprzez administrację i zarządzanie narzędziami zakupowymi. Ta druga grupa (ok. 20 osób) pozostała w strukturach Philips, dając początek nowej organizacji, jaką jest do dziś działające w Łodzi i Szanghaju Sourcing Services Center (SSC). SSC składa się z dwóch zespołów, potocznie nazywanych: Content Team (wsparcie procesów zakupowych) i Sourcing Team (analiza rynku dostawców, współpraca i zarządzanie dostawcami, kontrakty itd.).

\subsection{Zakres usług}

Głównym założeniem scentralizowanych zakupów jest odciążenie zamawiających od obowiązków transakcyjnych. W rezultacie proces wygląda tak, że potrzebujący precyzuje zamówienie na produkty lub usługi oraz termin ich dostawy, a globalna organizacja zakupowa, uwzględniając politykę i strategie asortymentowe, określa warunki, na jakich zamówienia mają być realizowane i u jakich dostawców. Dzieje się to zgodnie z procesem zakupowym Purchase to Pay (P2P).

Poszczególne działania podejmowane $\mathrm{w}$ ramach procesu $\mathrm{P} 2 \mathrm{P}$ zostały przedstawione na rysunku 3 .

Warto też wspomnieć, że efektywność tego procesu zwiększają powszechnie stosowane w Philips różnego rodzaju narzędzia elektroniczne.

Od 2007 r. działania PGP zmierzały do zawężenia zakresu odpowiedzialności kupców (działających w różnych częściach świata) jedynie do aktywności strategicznych i przeniesienia aktywności taktycznych i operacyjnych do organizacji scentralizowanej (SSC), jak ilustruje to rysunek 4 . 


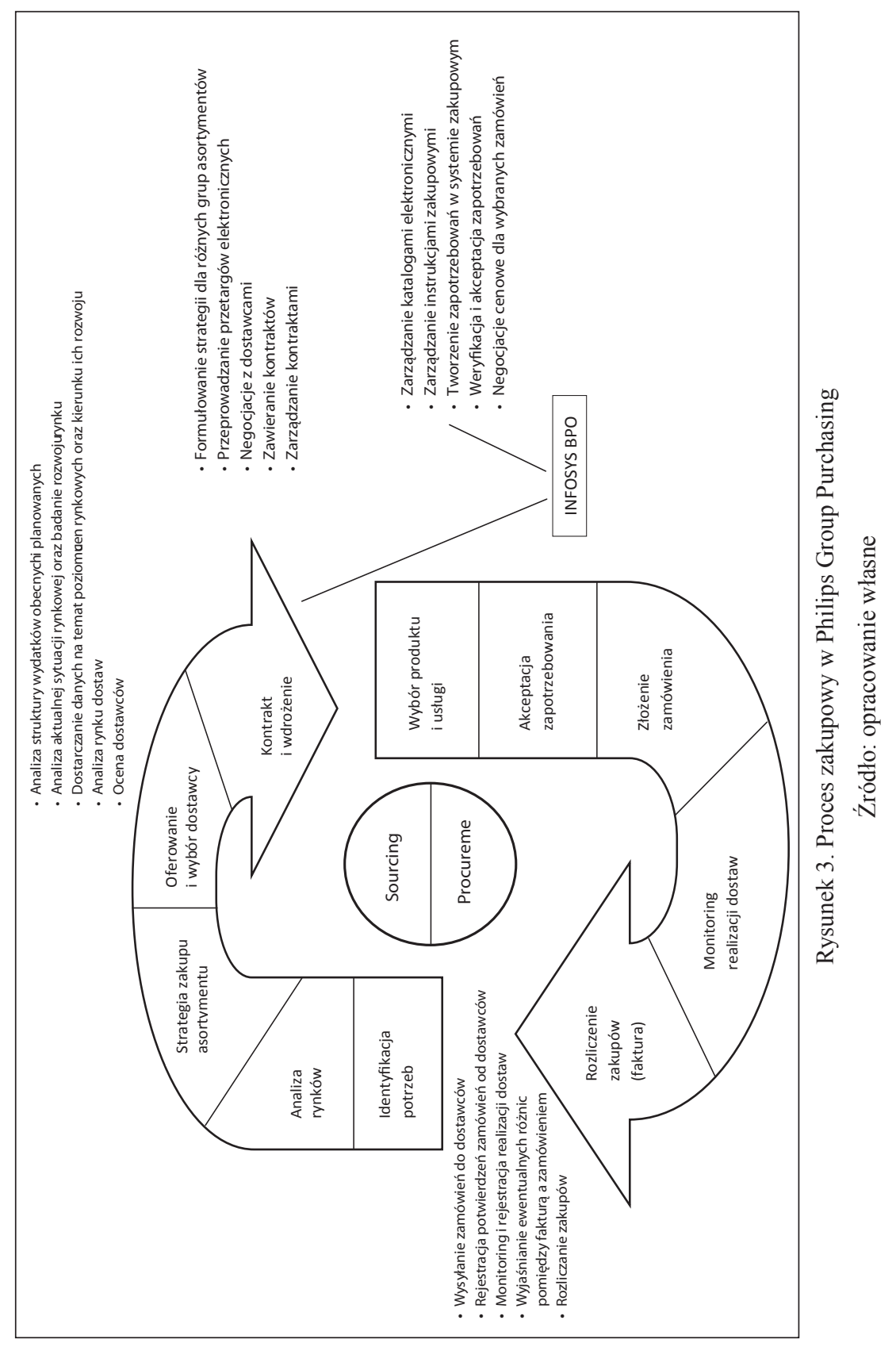




$\left.\begin{array}{|l|l|}\hline \multicolumn{2}{|c|}{2007} \\ \text { Sourcing strategiczny } & \text { Sourcing strategiczny } \\ \hline \text { Sourcing taktyczny } & \text { Sourcing taktyczny } \\ \hline \text { Sourcing operacyjny } & \text { Sourcing operacyjny }\end{array}\right\}$ SSC captive offshoring

Rysunek 4. Struktura zakupów nieprodukcyjnych w Philips Źródło: opracowanie własne

Taka integracja kupców taktycznych i operacyjnych oraz procesów zakupowych w jednym miejscu pozwoliła na wzrost efektywności pracy i procesów oraz redukcję kosztów organizacyjnych i barier komunikacyjnych.

Głównym celem Sourcing Services Center (SSC) jest wspieranie globalnej organizacji zakupowej (PGP) w aktywnościach operacyjnych i taktycznych, klientów wewnętrznych i Infosys (TSSC) w obszarach związanych z procesem zakupów nieprodukcyjnych. Dążeniem SSC jest również dalszy rozwój i specjalizacja w dziedzinie sourcingu i zarządzania projektami, umożliwiające przejmowanie nowych odpowiedzialności i stworzenie w pełni zintegrowanej organizacji zakupowej.

Zakupy nieprodukcyjne, po wdrożeniu modelu captive offshoring i outsourcing, można zobrazować tak, jak to przedstawiono na rysunku 5.

Zakres odpowiedzialności poszczególnych grup w procesie przedstawia się następująco:

\section{TSSC (partner BPO - Business Process Outsourcing):}

- pozyskiwanie ofert od dostawców,

- uzupełnianie, zatwierdzanie zapotrzebowań zakupowych,

- tworzenie finalnych zamówień,

- monitorowanie niedostarczonych zamówień,

- wprowadzanie zmian na zamówieniach,

- wyjaśnianie różnic pomiędzy zamówieniami a fakturami,

- tworzenie wniosków o wprowadzenie dostawców do systemów zakupowych. 


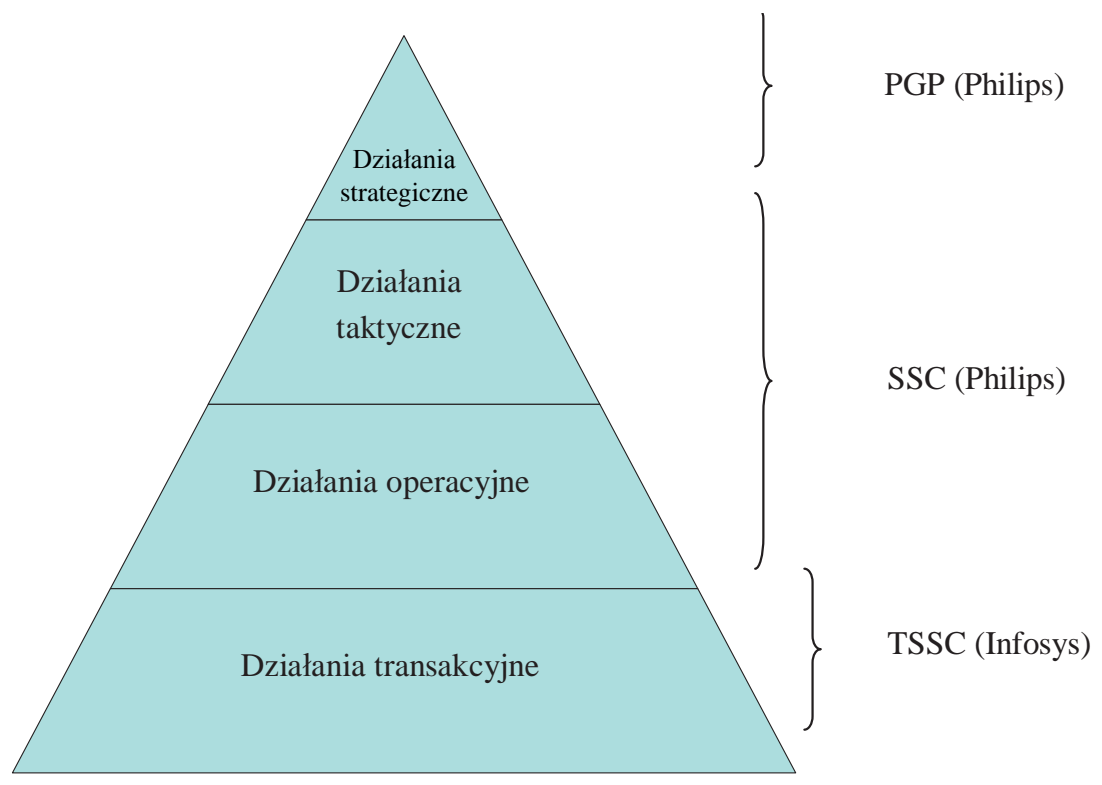

Rysunek 5. Struktura zakupów nieprodukcyjnych wewnątrz i na zewnątrz firmy Źródło: opracowanie własne

\section{Sourcing Services Center}

\section{Content Management:}

- wspieranie klientów wewnętrznych w procesie i narzędziach zakupowych,

- administrowanie i zarządzanie instrukcjami zakupowymi oraz katalogami produktów różnych dostawców (tworzenie i utrzymywanie),

- raportowanie i analiza danych, analiza rynku,

- organizowanie i monitorowanie e-Aukcji/Przetargów,

- wdrażanie i zarządzanie procesami, systemami i narzędziami zakupowymi,

- monitorowanie dostawców i kontraktów,

- zarządzanie bazą kontraktów i prowadzenie rankingów dostawców. 


\section{Operational i Tactical Sourcing:}

- wybieranie dostawców do grona preferowanych przez firmę,

- zarządzanie współpracą z dostawcami i klientami,

- przygotowywanie, negocjowanie, zawieranie i administrowanie kontraktami,

- merytoryczne przygotowanie i prowadzenie przetargów,

- raportowanie i analiza zapotrzebowania i podaży,

- zatwierdzanie wniosków zakupowych, zarządzanie wydatkami,

- uczestniczenie w procesie tworzenia dostawców w systemie zakupowym,

- prowadzenie lub udział w dużych projektach zakupowych,

- aktualizowanie instrukcji zakupowych.

\section{PGP - kupcy strategiczni:}

- rozwijanie strategii rynkowych, zapewnienie odpowiedniego udziału w rynku,

- obniżanie kosztów i zwiększanie ich elastyczności, zwiększanie płynności finansowej,

- rozwijanie i wdrażanie polityki i strategii zakupowej,

- tworzenie i wdrażanie rozwiązań zakupowych oraz instrukcji zakupowych,

- wdrażanie kontraktów,

- wspieranie klientów i zarządzanie relacjami z klientami,

- maksymalizacja wykorzystania zasobów organizacji zakupowej.

Centrum usługowe z założenia powinno być organizacją elastyczną, mogącą dostosować swoje rozmiary, struktury, kadry i portfolio do aktualnych potrzeb firmy. Takie właśnie jest Philips SSC Łódź, aktywnie uczestniczące w zmianach organizacyjnych firmy, niezmiennie potwierdzające swoją wartość dodaną, bez względu na zakres aktualnego działania. Organizację taką jak SSC można dość łatwo modelować i rozwijać, ponieważ posiada ona duży potencjał kadrowy (dostępność uczelni wyższych, szkół językowych) i funkcjonuje w korzystnych warunkach lokalizacyjnych (dostępność powierzchni biurowych, komunikacji publicznej). Kilka lat działania organizacji na łódzkim rynku potwierdza trafność wyboru tego miasta, jak również słuszność wyodrębnienia z firmy takiego podmiotu jak centrum offshoringowe. 


\subsection{Profil pracownika}

Jak wynika z badań przedstawionych w publikacji dr D. Ciesielskiej, zdecydowana większość pracowników zatrudnionych w firmach offshoringowych to osoby ze znajomością co najmniej jednego języka obcego, jak również posiadające wykształcenie wyższe.

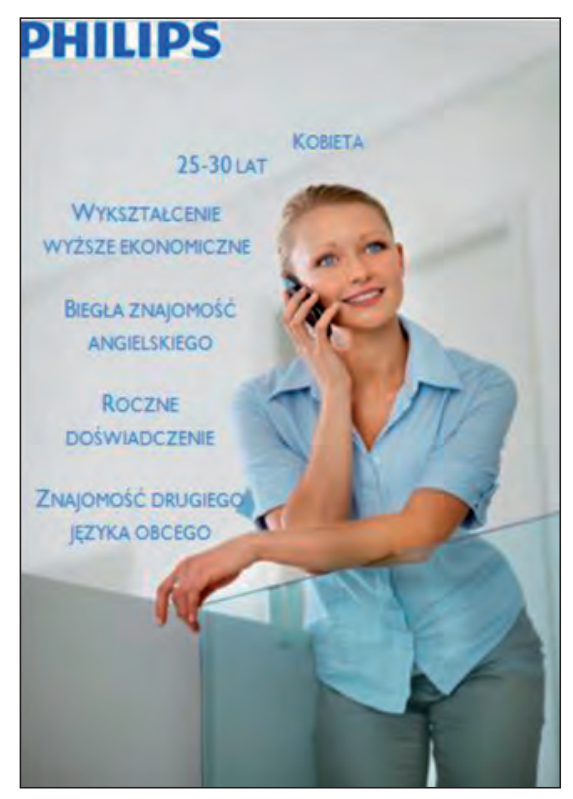

Fot. 3. Statystyczny profil pracownika SSC Łódź

Źródło: opracowanie własne

Pracownik o takim profilu jest obecnie najbardziej poszukiwany przez przedsiębiorstwa, które postanawiają przenieść swoją działalność poza granice kraju. Jednym z powodów jest niewystarczająca liczba osób ze specjalistyczną wiedzą, m.in. w dziedzinie studiów związanych z kierunkami matematycznymi oraz inżynierskimi ${ }^{16}$.

${ }^{16}$ D. Ciesielska, Offshoring ustug..., s. 104. 
Jak się okazuje, wyniki tych badań znajdują również odzwierciedlenie w charakterystyce zespołu SSC. W łódzkim oddziale Philips przeprowadzona została ankieta, której celem było sprawdzenie słuszności powyższej teorii. W tym celu opracowano poglądowy profil pracownika SSC, który mówi nam nie tylko o wykształceniu, ale także o innych aspektach kształtujących strukturę zespołu. $Z$ zebranych informacji wynika, iż statystycznym pracownikiem SSC Łódź jest kobieta w wieku 25-30 lat, urodzona i mieszkająca na terenie Łodzi, która uzyskała dyplom Uniwersytetu Łódzkiego na kierunku ekonomicznym. Przed podjęciem pracy w Philipsie pracowała przez okres kilku miesięcy, zdobywając doświadczenie zawodowe w innej organizacji związanej z zakupami. Ponadto zna dwa języki obce, a z jednego może pochwalić się certyfikatem językowym. Biegle włada językiem angielskim, jak również potrafi komunikować się w języku niemieckim bądź hiszpańskim.

Z informacji dotyczących pracowników Philips SSC Łódź wynika, że na stałe $\mathrm{w}$ firmie zatrudnionych jest 70 pracowników, z których zdecydowaną większość stanowią kobiety (75\%). Corocznie w okresie wakacyjnym do różnych działów dołącza również grupa stażystów mających możliwość zdobycia doświadczenia, jak również szansę późniejszego zatrudnienia w firmie. Ponad $90 \%$ zespołu to osoby narodowości polskiej, w tym ponad $60 \%$ urodzonych jest na terenie Łodzi. Warto jednak zaznaczyć, iż w naszym zespole są również osoby pochodzące z Grecji, Hiszpanii, Holandii, Indii, Portugalii oraz Węgier.

Jak wynika z przedstawionego poniżej wykresu 1, ponad $70 \%$ wszystkich pracowników zatrudnionych w SSC to osoby, które nie ukończyły 30. roku życia. Wśród nich są studenci ostatnich lat studiów, jak również absolwenci uczelni wyższych, dla których Philips jest pierwszym pracodawcą w życiu. Osoby, które zostały zakwalifikowane do grupy powyżej 31 lat, to w większości osoby z kilkuletnim doświadczeniem w naszej firmie, pracujące $\mathrm{w}$ organizacji od samych jej początków w Łodzi.

Ponad $80 \%$ naszych pracowników może pochwalić się wykształceniem zdobytym na łódzkich uczelniach wyższych - na Uniwersytecie Łódzkim (71\%) oraz Politechnice Łódzkiej (16\%). Zespół SSC to w połowie absolwenci różnego typu kierunków studiów ekonomicznych i zarządzania, jak również osoby z dyplomem ukończenia filologii 
angielskiej (wykres 2). Warto również podkreślić fakt, że 34\% zatrudnionych, ze względu na chęć rozwoju swoich umiejętności, postanowiło podjąć naukę na drugim kierunku studiów bądź, w przypadku 16\% - rozpocząć studia podyplomowe.

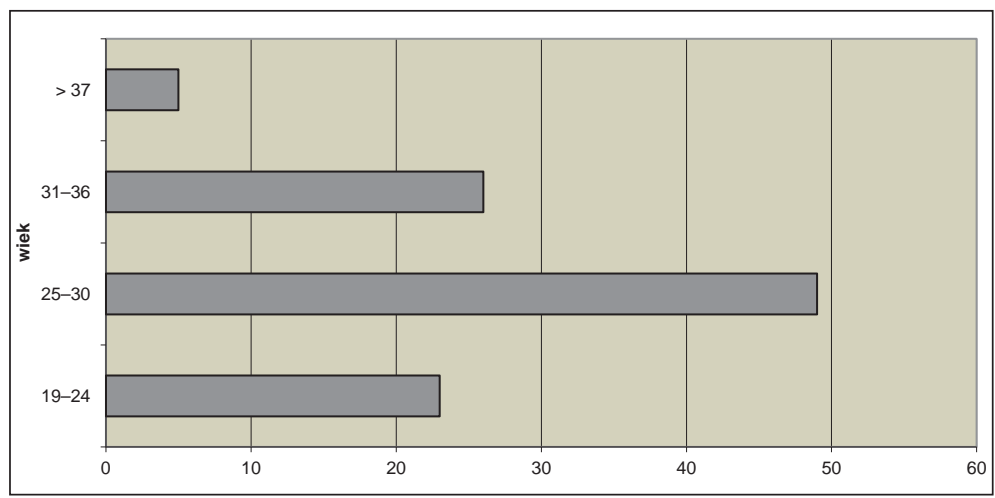

Wykres 1. Odsetek pracowników w danym przedziale wiekowym

Źródło: opracowanie własne

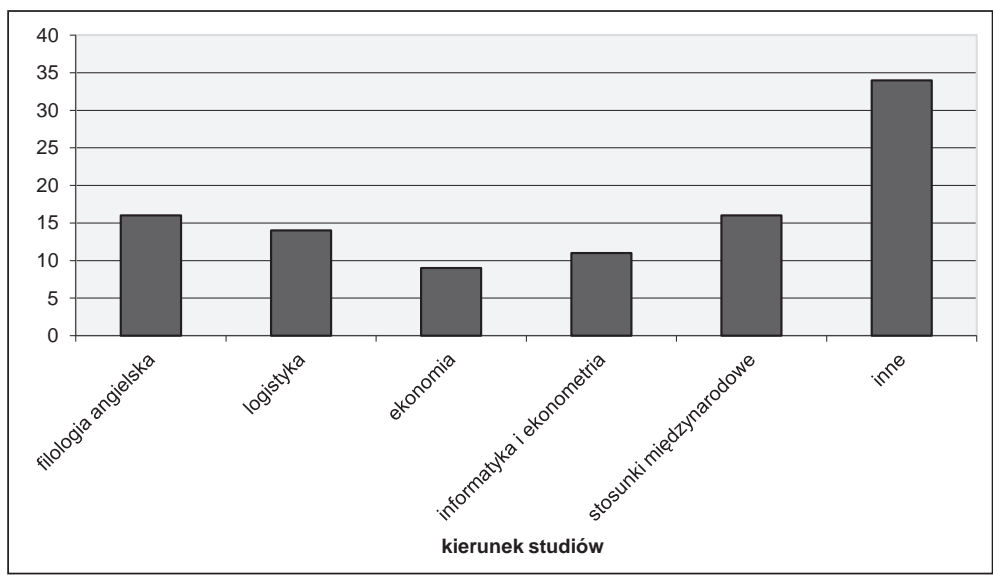

Wykres 2. Odsetek pracowników będących absolwentami danego kierunku studiów

Źródło: opracowanie własne 
Dla 30\% osób zatrudnionych, Philips SSC Łódź jest pierwszym miejscem pracy. W przypadku osób, które wcześniej miały możliwość zdobycia doświadczenia $\mathrm{w}$ innych organizacjach, średni czas zatrudnienia wynosił od kilu miesięcy do 2 lat (wykres 3). Ponad 20\% pracowników z wcześniejszym doświadczeniem miało możliwość pracy w dziale zakupów.

Warto również zwrócić uwagę na dane dotyczące umiejętności językowych pracowników SSC, które są niezmiernie istotne w organizacjach offshoringowych. 50\% pracowników posiada znajomość dwóch języków obcych, a 28\% - aż trzech. Najczęściej używanym w naszym zespole jest język angielski, którego dobra znajomość to warunek konieczny w codziennej komunikacji. Ponadto dużą popularnością cieszą się języki: francuski, niemiecki oraz hiszpański (wykres 4).

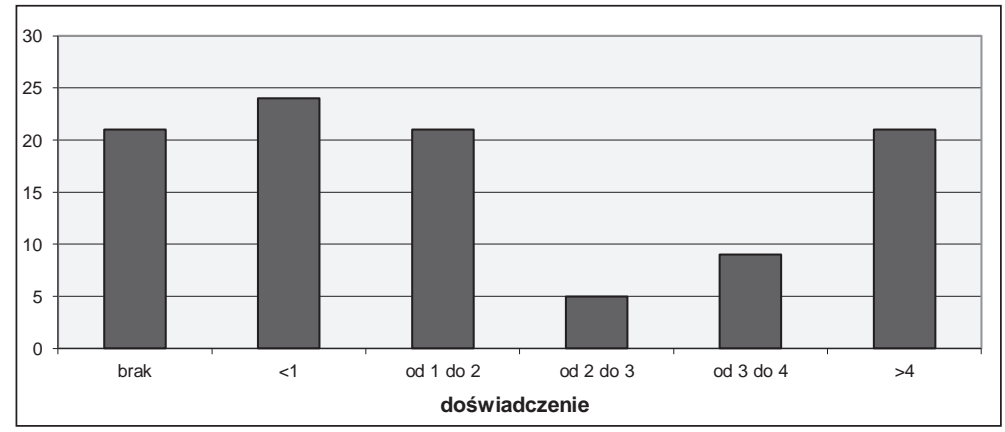

Wykres 3. Odsetek pracowników posiadających doświadczenie zawodowe przed podjęciem pracy w Philips

Źródło: opracowanie własne

Statystyki podane na wykresie 4 mogą być wskazówką dla przyszłych absolwentów, którzy chcieliby znaleźć pracę w biznesie usług offshoringowych. Znajomość języków obcych, wykształcenie wyższe oraz aktywność podczas studiów mogą stać się przepustką dla osób zainteresowanych pracą w międzynarodowym środowisku, w SSC Łódź. Kluczowe są również takie cechy, jak: otwartość, komunikatywność, umiejętność pracy w zespole. 


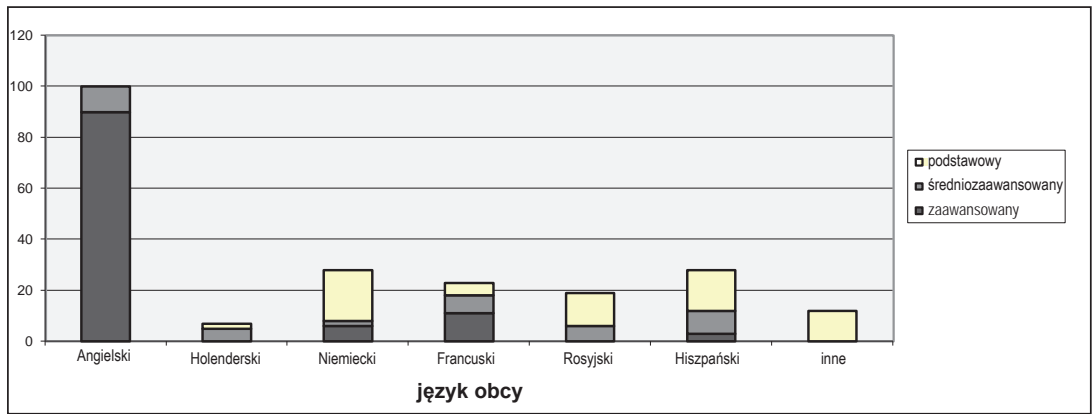

Wykres 4. Znajomość poszczególnych języków obcych wśród pracowników (w \%) Źródło: opracowanie własne

\section{Podsumowanie}

Obecne warunki gospodarki światowej wymuszają na przedsiębiorstwach zmianę strategii zarządzania działalnością. Firmy muszą wciąż zabiegać o utrzymanie swojej konkurencyjności i odpowiedniej pozycji na rynku. Globalizacja, a co za tym idzie rozwój technologii rozszerzyły wachlarz narzędzi i rozwiązań, które mogą być w tym celu wykorzystane. Jednym z nich jest offshoring, który obecnie staje się coraz powszechniejszą strategią stosowaną w reorganizacji dotychczasowych struktur przedsiębiorstwa.

Niniejszy artykuł wykazał, jak ogromne znaczenie zyskują nowoczesne modele biznesowe oparte na przetransferowaniu części działalności poza granice kraju, przy jednoczesnym zachowaniu dotychczasowej lokalizacji kluczowych obszarów. To rozwiązanie pozwala nie tylko na obniżenie kosztów operacyjnych, ale i w wielu przypadkach - na wzrost efektywności i jakości świadczonych usług.

Zgodnie ze strategią firmy Royal Philips Electronics kolejne oddziały tworzone są w takich lokalizacjach, gdzie zasoby najlepiej odpowiadają wymaganiom danej jednostki. Dzięki temu przedsiębiorstwo 
umacnia swoją pozycję, pozyskując odpowiedni kapitał ludzki, dopasowany do konkretnych potrzeb biznesowych. Powstały w 2007 r. Philips Sourcing Services Center świadczy usługi zakupowe dla całej firmy w skali globalnej. Satysfakcjonujące rezultaty działania sprawiają, że centrum wciąż się rozwija, rozszerzając zakres swoich odpowiedzialności.

Odległość geograficzna, różnice kulturowe oraz stref czasowych pomiędzy jednostkami scentralizowanymi a siedzibą i klientami wewnętrznymi mogą powodować utrudnienia w zarządzaniu i komunikacji. Dlatego też kluczowym czynnikiem decydującym o sukcesie firmy są jej pracownicy. Komunikatywność oraz chęć pracy w zespole są niezwykle istotne przy wyborze strategii offshoringu.

\section{Bibliografia}

\section{Wydawnictwa książkowe}

Ciesielska D., Offshoring ustug wplywa na rozwój przedsiębiorstwa, Wydawnictwo Oficyna Wolters Kluwer business, Warszawa 2009, s. 11, 32-34, 78, 104

Kłosiński K., Masłowski A., Globalizacja sektora usług w Polsce, Polskie Wydawnictwo Ekonomiczne, Warszawa 2005, s. 15-16

Szymaniak A., Globalizacja Ustug, Outsourcing, Offshoring i Shared Service Centers, Wydawnictwo Akademickie i Profesjonalne, Warszawa 2008, s. 189-191

\section{Czasopisma}

M. Kaczmarczyk, Hit eksportowy, „Forbes” 2012, No 9

Sytuacja społeczno-ekonomiczna w Łodzi, BIP 2011

UNCTAD, Word Investment Report 2004. The Shift Towards Services, United Nations Conference on Trade and Development, New York, Geneva 2004, s. 147

„Outsourcing \& More” 2012, No 4(5), s. 38

\section{Strony internetowe}

www.bpo.lodz.pl [dostęp: 07.09.2012]

www.uml.lodz.pl [dostęp: 03.09.2012]

www.egospodarka.pl [dostęp: 29.08.2012]

www.interbrand.com [dostęp: 21.08.2012]

www.ceo.cxo.pl [dostęp: 14.09.2012]

www.sterlinga-bc.pl [dostęp: 14.09.2012] 